研筧然表

老年心筋梗塞再発症例の臨床所見及び経過について

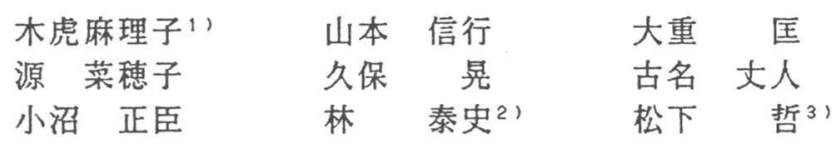

Clinical Observation and Course of the Second Attack of Myocardial Infarction in the Aged.

Mariko KITORA, RPT ${ }^{1}$ ', Nobuyuki YAMAMOTO, RPT, Tadasu 00SHIGE, RPT, Nahoko MinAMOTO, RPT, Akira KUBO, RPT, Kaketo FURUNA, RPT, Masaomi ONUMA, RPT, Yasufumi HAYASHI, MD' ', and Tetu MATSUSHITA, MD ${ }^{3}$.

1) Department of Physical Therapy, 2) Department of Rehabilitation, Tokyo Metropolitan Geriatric Hospita1: 35-2 Sakaecho Itabashiku Tokyo (173) Japan. TEL 03-964-1131.

3) Tokyo Metropolitan Tama Geriatric Hospital.

J. Exercise Physiol. 3(1):43-48, 1988. ISSN 0912-7100. Spoke Nov. 8, 1987. ABSTRACT

Clinical observations and course of the second attack of myocardial infarctions of twenty aged over 65 years old in Tokyo Metropolitan Geriatric Hospital were statistically investigated.

Results obtained were as follows: (1) No significant correlation between maximum value of $C P K$, deviating enzyme from cardiac muscle cells, and rate of left ventricular ejection was observed. (2) With respect to subjective symptom, inpatients who complained of dyspnea had a tendency to have more serious cardiac insufficiency than those who complained of lumbagos. (3) The rates of left ventricular ejection of two infarction parts, subendocardial layer and the other part, were compared, and the former part showed higher points. (4) All the inpatients examined had some of four risk factors, and anamnesis of other diseases. (5) The average period from the second attack to the end of rehabilitation was 66.8 days. (6) Levels of ADL between in the period before the second attack and in that after being compared using NYHA grouping standards, the latter indicated lower result.

key words: myocardial infarction, second attack, rehabilitation

要旨

東京都老人医療センターに入院した65歳以上の再梗塞患者 20 例を対象に、老年心筋梗塞再発 症例の臨床所見及び経過について調查した。その結果は(1) Peak CPK值と左室駆出率の間では有 意な相関関係は認めなかった。(2)自覚症状で胸痛を訴えたものよりも呼吸困難を訴えたものの 方が心不全の程度はより重症であった。(3)再梗塞部位を心内膜下とその他の梗塞の2群に分け 左室駆出率で比較検討すると心内膜下群の方が左室駆出率は保たれた状態にあった。(4)全症例 にrisk factorあるいは他の疾患の既往があった。(5)発症からリハビリテーション終了までの 施行期間の平均は66.8日であった。(6) NYHAの分類を基準にしたADLで再梗塞前と後を比べると 再梗塞後は以前の状態よりも低いレベルにあった。

き价ド:心筋梗塞，再発例，リハビリテーション

1) 東京都老人医療センター 理学療法科：東京都板橋区栄町35-2（テ173） TEL 03-964-1131.

2)同 リハビリテーション部. 3) 東京都多摩老人医療センター 循環器科.

運動生理 3(1):43-48, 1988. 発表日1987年11月8日（渾動生理研究会学術集会）. 
I はじめに

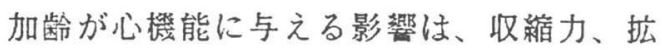
張能、予備力の低下などが挙げられる。江本 1)によると、心筋梗塞の合併は心機能を更に 低下させポンプ失調に陥り易い、と報告して いる。このことから、心筋梗塞の発症は重要 な予後規定因子となると考えらる。また、心 筋梗塞再発について、Russekら 2'は, 2年以内 に30\%の症例が再発を起こし，また高橋ら ${ }^{3)}$ は、 始めの 1 年間にやや多発しその後は 4 - 5 年の 間に再び増加する傾向がみられたと報告して いる。このように再発についての報告は、再 発の頻度に関するものが多く、再発例の臨床 所見や経過についての報告はあまりなされて いない。

そこで、今回我々は、高齢者の再発例に重 点をおいてその臨床所見や経過について現状 を調査したので報告する。

\section{II 対象と調查項目}

対象は、昭和 60 年 4 月から蛁和 62 年 8 月まで の2年5力月間に急性心筋梗塞で東京都老人医 療センターに入院した65歳以上の再梗塞患者 でリハビリテーションを施行した男性13例、 女性7例計 20 例で平均年齢78.2歳である。

調查項目は、重症度分類として、Killipと Forresterの分類、自覚症状, 再梗塞部位と初 回梗塞部位、過去の梗塞回数と再発期間、 risk factor として高血圧・糖尿病 · 高脂血 症・喫煙の有無、病識の有無、リハビリテー ション施行期間、各レベルの施行期間、過去 のリハビリテーション施行の有無、再梗塞前 後でのADL等を調查した。

III 結果及び考察
(1) 重症度分類

Table 1に、KillipとForresterの分類を示 した。Ki11ipの分類は、理学的検査による心 不全の重症度分類でその内訳は I 群 5例、II 群2例, III 群7例, IV 群1例, 未検査5例であった。 また、Forresterの分類は、Swan-Ganz力テー テルから得られる血行動態により心機能を評 価するもので、その内訳は I 群5例、II 群4例、 III 群5例、IV 群1例、未検査5例であった。

(2) Peak CPK值と左室駆出率

Table 2 に示すとおりPeak CPK値の平均は $1034.44 \pm 851.11$ (IU)、最大 3141 (IU)、最小 198 (IU)、左室駆出率の平均は32.38 $14.53 \%$ 、 最大 $66 \%$ 、最小 $12 \%$ であった。

心筋梗塞発症後、心筋細胞からの逸脱酔素 としてCPK、GOT、LDHなどが挙げられる。そ のなかでもPeak CPK值は梗塞巣の大きさを反 映し、推定することが可能であり、また左心 機能とも密接な関係にあると言われている。 そこで、Peak CPK値と左室駆出率について比 較検討をしたが有意な相関関係は認められな かった。

(3)自覚症状

自覚症状の訴えを胸痛、呼吸困難、その他

Table 1. KillipとForresterの分類（症例数）

\begin{tabular}{lr|cccccc}
\hline & \multicolumn{6}{|c|}{ Forresterの分類 未検查 計 } \\
& I & II & III & IV & \\
\hline Ki11ip & I & 3 & 1 & 1 & & & 5 \\
の & II & & 1 & 1 & & & 2 \\
分類 & III & 1 & 2 & 3 & 1 & & 7 \\
& IV & 1 & & & & & 1 \\
未検查 & & & & & 5 & 5 \\
\hline 計 & 5 & 4 & 5 & 1 & 5 & 20 \\
\hline
\end{tabular}

Table 2. Peak CPK值と左室駆出率

\begin{tabular}{l|ccc}
\hline & 平均値 & 最大値 & 最小值 \\
\hline Peak CPK値(IU) & $1034.44 \pm 851.11$ & 3141 & 198 \\
左室駆出萃(\%) & $32.38 \pm 14.53$ & 66 & 12 \\
\hline
\end{tabular}




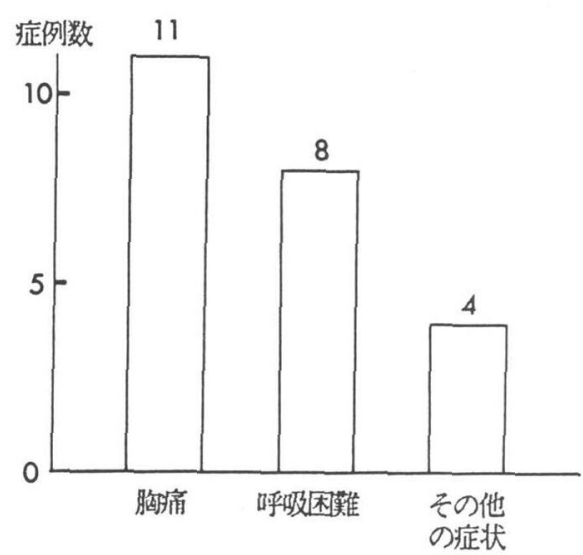

Fig. 1. 自筧症状の内訳

の症状の3つに分けて調查し、Fig.1に示した。 胸痛を訴えたものは11例、呼吸困難を訴えた ものは8例、その他の症状を訴えたものは4例 であった。このうち胸痛と呼吸困難の両方を、 また胸痛とその他の症状、呼吸困難とその他 の症状の両方を訴えたものが1例ずつあった。 その他の症状としては、嘔吐、胸部圧迫感、 全身倦急感を訴えていた。

次に、胸痛を訴えたものと呼吸困難を訴え たものとを2群に分け、心不全の病態把握に用 いられているForresterの分類とで比較検討し たところ有意な差を認め、胸痛を訴えたもの よりも呼吸困難を訴えたものの方が心不全の 程度としてはより重症であった。また、自覚 症状の違いでADLに差があるか検討したが特に 関係は認められなかった。

池田ら“は、老人の心筋梗塞の臨床的特徴 として定型的症状を示すものはむしろ少ない と述べており、また小田ららによれば痛みの 認識には主観的要素が関与し、とらえかたは 各人千差万別であろうし、老年者の場合には 正確な聴取は、特に困難であると述べている。 無痛性の要因については、痛みの闘値の加齢 に伴う上昇、他の症状, 例えば呼吸困難、シ ヨック等でマスクされる自律神経のdysfunction、中枢神経の障害や知覚神経の障害など

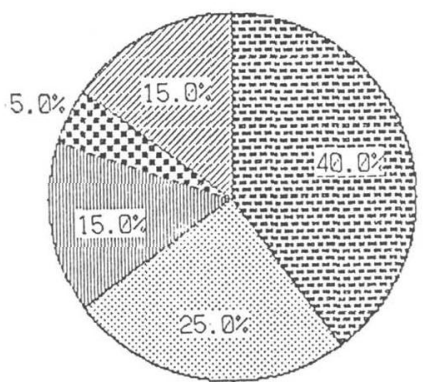

盒 心内豁下 8 例

前壁 5 例

西策 3例

後壁 1 例

翟不明 3 例

Fig. 2. 再梗塞部位の内訳

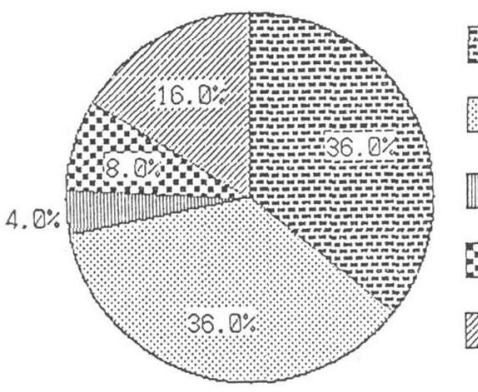

哄前壁 9例

㺟下壁9例

鮞侧壁 1 例

3心内膜下 2 例

漗不不明 4 例

Fig. 3. 初回梗塞の内訳

が挙げられる。今回も、老年者では心筋梗塞 の特徴である胸痛を自覚症状として訴えない ものがみられた。

(4)再梗塞部位と初回梗塞部位

再梗塞部位の内訳では、Fig. 2 に示すとお り、前壁5例、下壁3例、後壁1例、心内膜下 8例、不明3例で心内膜下が全体の $40 \%$ を占め ていた。また、初回梗塞部位の内訳はFig.3 に示すとおりで前壁、下壁に最も多い梗塞を 示し、再梗塞と初回梗塞では部位に違いがあ った。本田 ${ }^{1}$ によると再梗塞を発症した例は 入院中の狭心発作の合併および非貫壁性梗塞 の頻度が有意に高かったと述べているが、我 々の結果では貫壁性梗塞の前壁、下壁に既往 のあるものに再梗塞をおこしやすいという傾 向が見られた。

次に、心内膜下梗塞群とその他の梗塞群の 左室駆出率で比較検討を行った。その結果、 心内膜下梗塞群の左室駆出率の平均は 42.14 
土15.36\%、その他の梗塞群の左室駆出率の平 均は 26.18土10.40\%で有意な差を認めた。ま た、全体の左室駆出率の平均より心内膜下梗 塞群の平均の左空駆出率の方が高かった。こ れらのことから、心内膜下梗塞群の方が左心 機能は比較的保たれた状態にあると考える。 しかし、心内膜下梗塞群とその他の梗塞群と の間でのADLの関係について検討をしたが有意 な差は認められなかった。以上のことから考 えると、左室駆出率が比較的保たれた状態に あっても、一概にADLも良い状態にあるとはい えない。

(5)過去の梗塞回数と再発期間

過去に梗塞を起こし、その際にリハビリテ ーションを施行していたのは6例であった。 また、今回の入院で検査により初めて過去に 梗塞を起こしていたと診断された症例は6例 であった。

最高梗塞回数は、今回を含めて6回目1例、 4 回目1例、3回目2例、残り12例は2回目である。

再発期間は、1年以内が 10 件、そのうち半年 以内が 7 件、 2 年以内が 4 件、 3 年以内が 4 件、 4 年以内が 4 件、 5 年以内が 1 件、それ以上が 1 件 と言う結果であった。このことから、Russek や高橋らの報告に似通った結果が得られてい るといえる。

(6)risk factorとその他の疾患の既往

Fig. 4 に示すとおり、高血圧、糖尿病、高 脂血症、夕バコの4つの risk factorのうち 1 つでも有していたものは20例中18例で全体の $90 \%$ 占㜭り、その中で2つ以上の risk factorを有していたものは13例で全体の50\% を占めていた。risk factorを1つも有さなか つたものは2例であった。その他の疾患の既 往についてはFig.5に示したが、risk factor 以外の他の疾患を有するものは13例で全体の 65\%であった。それぞれの risk factorとADL との間には有意な差は認めなかったたが、ど の症例も何らかの risk factorかその他の疾 患の既往をもっており、患者の疾患に対する

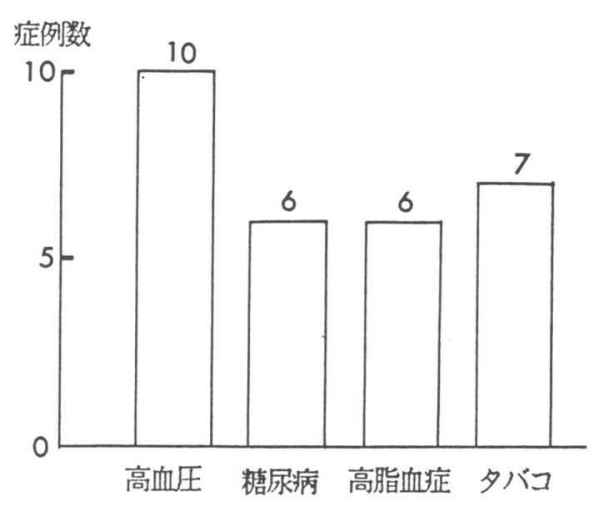

Fig. 4. risk factorの内訳

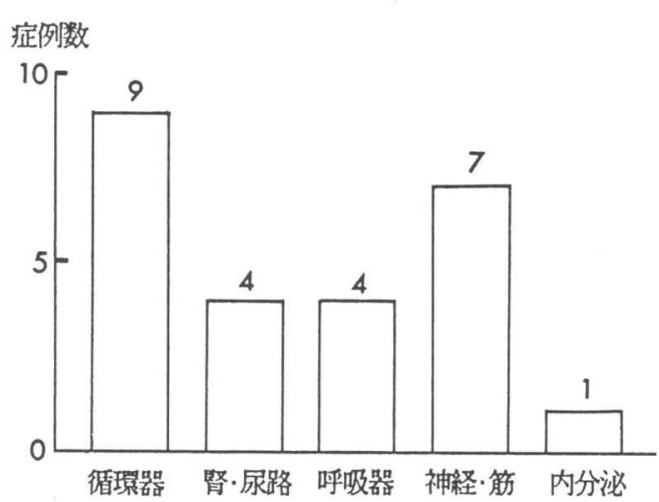

Fig. 5. 既往歴の内訳

認識やリハビリテーションを施行する上で患 者の全身状態を十分に把握して行う必要があ ると考える。

(7)リハビリテーション施行期間と各レベル リハビリテーション施行期間は、発症から リハビリテーション終了まで平均66.8日で、 これはリハビリテーション中止期間も含んだ 日数である。当センター作成の6段階リハビ リテーションプログラムを中心に施行したが、 狭心症や不整脈などが出現したり CCUに再入 室したりで中止期間を要したものが8例あっ た。最終到達レベルは、レベル2からレベル 6までで、Treadmil1 testを施行したものは 20例中6例で全体の30\%を占め、左室駆出率を 
Table 3. 発症から各レベル開始までの期間と各レベルの平均期間（日）

\begin{tabular}{|c|c|c|c|c|c|c|}
\hline & $\begin{array}{l}\text { ル゙ル1 } \\
\text { Bed上 }\end{array}$ & $\begin{array}{l}\text { ル゙ル2 } \\
\text { Bedフキy }\end{array}$ & $\begin{array}{l}\mathrm{M}^{*} ル 3 \\
\text { 病室内 }\end{array}$ & $\begin{array}{l}\text { 以゙" } 44 \\
\text { 病梀 }\end{array}$ & $\begin{array}{l}\text { ベル5 } \\
\text { 病院内 }\end{array}$ & $\begin{array}{l}\text { ベN6 } \\
\text { 屋外 }\end{array}$ \\
\hline $\begin{array}{l}\text { 発症から.各レベ } \\
\text { ル開始きでで期間 } \\
\text { 各レベルの }\end{array}$ & 19.0 & 21.5 & 30.2 & 31.3 & 38.0 & 53.4 \\
\hline 平均期間 & 10.0 & 13.9 & 10.4 & 18.7 & 12.2 & 9.0 \\
\hline
\end{tabular}

Table 4. NYHAの分類を基準にした 再梗塞前と後のADL（症例数）

\begin{tabular}{|c|c|c|c|c|c|c|}
\hline & $\begin{array}{c}\text { 再梗 } \\
\text { I }\end{array}$ & $\begin{array}{l}\text { 塞 } \\
\text { II }\end{array}$ & III & $\begin{array}{l}\text { DL } \\
\text { IV }\end{array}$ & $\begin{array}{l}\text { 不 } \\
\text { 明 }\end{array}$ & 計 \\
\hline I & 1 & 1 & 1 & & & 3 \\
\hline 再梗塞 II & & 5 & 5 & & 1 & 11 \\
\hline 前の $\mathrm{III}$ & & 2 & & & & 2 \\
\hline ADL IV & & & & 1 & & 1 \\
\hline 不 明 & & & 3 & & & 3 \\
\hline 計 & 1 & 8 & 9 & 1 & 1 & 20 \\
\hline
\end{tabular}

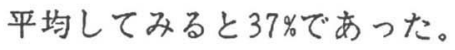

発症から各レベル開始までの期間、各レベ ル施行の平均期間はTable 3 に示した。各レ ベルにおいて、最も期間を要しているのはレ ベル4で18.7日、次いでレベル2の13.9日、レ ベル5の12.2日であった。

久保らヤの報告を参考に見てみると、これ は再梗塞も含まれた報告ではあるが、全体的 にみてそれぞれのリハビリテーション施行期 間は延長されている。

(8)再梗塞前と後のADLと病識

NYHAの分類の基準を用いて再梗塞前と後の ADLをTable 4 に示した。再梗塞前と後のADL について比較検討をしたところ有意な差を認 め、再梗塞を起こす前に比べて再梗塞を起こ した後のADLの方が低い状態にあるという結 果を得た。このことから、再梗塞を起こした 場合、以前より ADLが低下することはあって も再梗塞を起こす前以上の ADLレベルには回 復しがたいと言える。

病識においても、20例中12例については欠 けており、また老年者の場合、精神活動面の
低下を合併していることも考えられ、リハビ リテーション施行後のADL指導に大きな影響を 与えると考える。

\section{IV まとめ}

当センターに急性心筋梗塞で入院した65歳 以上の再梗塞患者20例を対象に調查を行った。 (1) Peak CPK值と左室駆出率の間では有意な相 関関係は認められなかった。(2)自覚症状とし て胸痛以外の訴えは呼吸困難、嘔吐、胸部压 迫感、全身倦急感を訴えた。又、胸痛を訴之 たものよりも呼吸困難を訴之たものの方が心 不全の程度としてはより重症であった。(3)再 梗塞部位では、心内膜下梗塞が全体の $40 \%$ を 占め、初回梗塞部位では、前壁梗塞と下壁梗 塞が全体の72\%を占めていた。再梗塞部位を 心内膜下梗塞群とその他の梗塞群に分け左室 駆出率と比較検討すると心内膜下梗塞群の方 が左室駆出率は保たれた状態にあった。(4)全 症例とも、なんらかのrisk factorあるいは、 その他の疾患を既往していた。(5)発症から、 リハビリテーション終了までの施行期間の平 均は66.8日で、そのうち6例はレベル6まで到 達した。(6) NYHAの分類を基準にしたADLで再 梗塞前と後を比べると再梗塞後は以前の状態 よりも低いレベルにあった。

今回は、再梗塞20例について調查しました が、今後さらに初回梗塞との比較検討を重ね ていきたいと思う。 


$$
\text { 引用文 献 }
$$

1)江本二郎：老年者の急性心筋梗塞における 血行動態的特徵とその予後診断的価値に ついて. 日老医誌, 23：565-571, 1986.

2) Russek, H. I. and Zohman, B. L. :The natural history of coronary atheosclerosis. Coronary heart disease, ed. by Russek, H. I. \& Zohman, B. L., B. J. Lippincott, Philadelphia \& Toronto, p. 167, 1971.

3) 高橋宣光 ·他 : 心筋梗塞の経過と長期予後
心躟 6:499-510， 1974.

4)池田正男 ·他：老人の心筋梗塞, 木村栄一 編，虚血性心疾患. 文光堂, p. 161, 1979.

5) 小田爾二. 他：老年者心筋梗塞と胸痛, 無 痛性梗塞について。日老医誌 23:600-604 1986.

6)本田喬: 心筋梗塞の再発予防. 綜合臨林, 36: 949-953, 1987.

7) 久保晃 - 他 : 高齢者急性心筋梗塞のリハビ リテーションの現状報告. 第5回関東甲信越 ブロック理学療法士学会講演, 1986. 